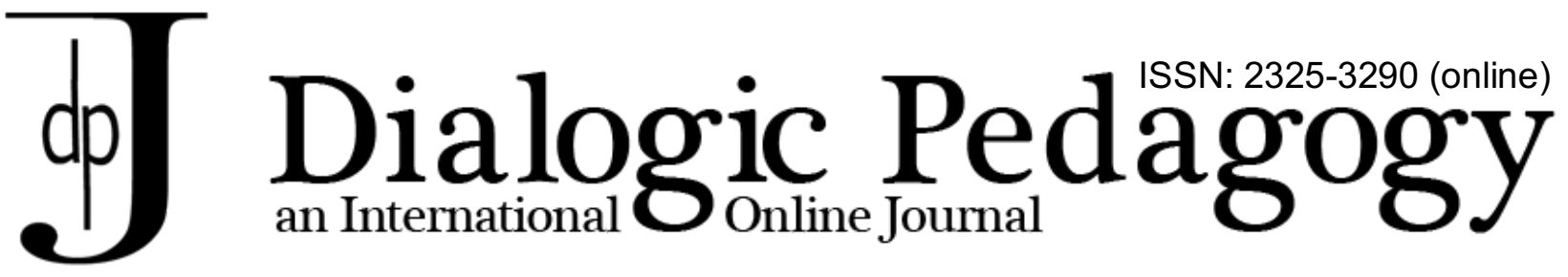

\title{
The Golden cage: Growing up in the socialist Yugoslavia
}

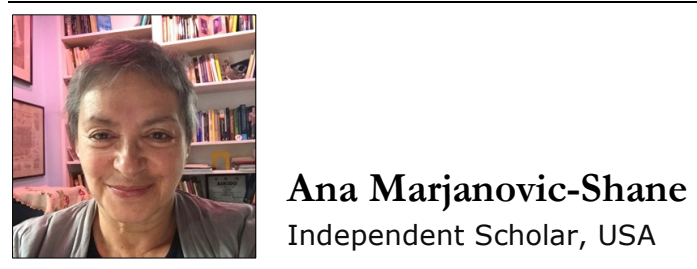

\section{Abstract}

From the mid 1950s through roughly the 1980s, some or many children and youth of the Socialist Yugoslavia, especially those of us in Belgrade, the capital, lived in a curious, almost surreal "window" in the space and time. This surreal window of space-time, offered to children and youth of Yugoslavia, unprecedented opportunities for personal development, exposure to the classic cultures and the newest events in the cultural worlds from all over the world, freedom of speech, gathering, activism and opportunities to travel and interact with a multitude of people of the world who came to Yugoslavia. Such special window in time and space sounds impossible to believe, all the more, in the light of the subsequent brutal and bloody civil wars of the 90s in which Yugoslavia perished. And yet, for many of us this window in time and space did exist! It was a product, I think, of several paradoxical tensions that may have created unprecedented loopholes in the fabric of an otherwise authoritarian and often brutal regime that had its ugly underside in suppression of any actions and words which would be critical of the ruling regime and its leaders.

One could arguably say, that, when I talk about this curious, surreal time, I talk from a point of view that can only belong to the children of the privileged: children of the high officers of the Communist party, of the Belgrade political, intellectual, cultural and economic elite. Of course, in many ways, I cannot escape, some of the privileged vistas of my own background - as no one can entirely escape the bent of their own lives. However, my privileged view comes from being among the intellectual elite of Belgrade, rather than the political elite. But my views were also based on the experiences of "ordinary" others which I shared in the everyday ways of life in which I was not segregated from everyone else: my neighbors, school mates, people I met in various other gathering places.

In this auto-ethnographic essay, I explore a uniqueness of my Socialist Yugoslav childhood, where a lot of children and youth lived as if in a golden cage. This golden cage had an internal reality that was in many ways protective of our wellbeing. In this reality we experienced freedoms, stood for justice, had many opportunities to participate in cultural clubs, art studios, musical bands, poetic societies, sports clubs, summer and winter camps, etc. At the same time, the world that surrounded us, and even in many ways created our childhoods, was harsh, often brutal and did not hold any of the high ethical principles and values that we believed and lived in.

Ana Marjanovic-Shane is an Independent scholar in Philadelphia, USA. She studies meaning making in human development, dialogic educational relationships and events, democracy in education, dialogic teacher orientation, the role of imagination, drama, play and critical dialogue in education. In her studies, she is developing a dialogic sociocultural paradigm, inspired by a Bakhtinian dialogic orientation. Her articles were published by "Mind, Culture, Activity Journal", "Learning, Culture and Social Interaction", and as book chapters in books on play, education, and democracy. Her most recent publication is: MarjanovicShane et al, (2017). Idea-dying in critical ontological democratic dialogue in classrooms. Learning, Culture and Social Interaction.

Acknowledgements: I am thankful to my colleagues Eugene Matusov, Lei Chen and Marek Tesar for their feedback and support. I am also thankful to my community of "Jakljanci," Micko Jojkic, Ivana Stambolic, 
Dusan Glusac, and many others, who shared their memories on our online site, in personal emails, and in endless "symposia" in Belgrade Caffees, in discussions about what was true or not true about our childhoods.

$\cos 0380$

\section{Introduction}

I grew-up in the Socialist Federal Republic of Yugoslavia in the 50s and 60s. Even today it is hard for me to say "former" Yugoslavia - as my personal memories, as well as the memories of many of my close and distant friends and acquaintances from Belgrade, are mostly memories of closely knit families and communities, of rich personal and cultural experiences, of many opportunities we had to be creative. We felt equal to anyone. We often interacted with people of culture, considered to be the most renowned in their professions: artists and scientists, film and theater actors and directors, world travelers, adventurers, writers and poets, and others. In the span of about 30 something years (from the late 50 s and the start of the $60 \mathrm{~s}$, through the end of the 80s) children and youth of Yugoslavia, especially those of us in big cities like Zagreb, Sarajevo, Ljubljana, Skoplje and particularly, Belgrade - the capital of Yugoslavia, lived in a curious, almost surreal "window" in space and time - in an unparalleled "chronotope." We had (and usually took for granted), extraordinary opportunities for personal development, cultural, artistic, scientific and ideological becoming. The children and youth of Yugoslavia were exposed to the classic cultures (through literature, theater, museums and movies) and the newest events in the cultural worlds from all over the world (through new popular youth music, avant-garde theater performances, international film festivals, translations of the newest literary works from all over the world, etc). They enjoyed relatively a much greater freedom of speech, gathering and activism than most of their counterparts in other socialist countries, and they had opportunities to travel abroad and interact with people from all around the world who visited Yugoslavia. That is not to say that the life in Yugoslavia was a paradise of overall prosperity and full democratic ideological freedoms, with no dramatic events, confrontations and clashes with the ruling communist governmental bureaucracy. Yet, there was something different and unique about the possibilities and the opportunities of life that was experienced by many in our generations ${ }^{2}$ - that is worth exploring and understanding. Such special window in time and space sounds impossible to believe, all the more, in the light of the subsequent brutal and bloody civil wars of the 90s in which Yugoslavia perished. And yet, for many of us, this window in time and space did exist! Paradoxically, it's existence is a result of many tensions, crises and contradictions of the "Yugoslav project" (Spaskovska, 2017, p. 15).

This curious and contradictory "time-space window" grew slowly and almost imperceptibly out of a far harsher authoritarian, if not outright totalitarian communist rule in Socialist Yugoslavia in the aftermath of the WWII and a period of the close ties between the Yugoslav the Soviet Union leadership. But as Yugoslavia moved away from the Soviet Union, turning toward the West, and as it started to change from a poverty stricken, largely agrarian society, ravaged by the WWII, toward a more progressive economic growth of industrialization gaining a momentum in the 50 s, and toward becoming an international leader of the movement of the Non-Allied countries at the start of the 60 s, the life opportunities and the overall cultural and political climate were becoming increasingly open for the children and youth.

\footnotetext{
${ }^{1}$ A "chronotope" is a unity of time, space and axiology, i.e., a set of values, relationships, rules and expectations that exist for the participants in a time-space. Bakhtin described chronotope in literature as "the intrinsic connectedness of temporal and spatial relationships that are artistically expressed... [S]patial and temporal indicators are fused into one carefully thought out, concrete whole. Time, as it were, thickens, takes on flesh, becomes artistically visible; likewise, space becomes charged and responsive to the movements of time, plot and history" (Bakhtin, 1994, p. 184).

${ }^{2}$ People mostly born in the 50 s and 60s. For more discussion of the definition of a "generation" and its significance for historical analysis (especially of Yugoslavia) see Spaskovska (2017).
} 
One could arguably say, that, when I talk about this curious, almost surreal time, I talk from a point of view that can only belong to the children of the privileged: children of the high officers of the Communist party, children of the Belgrade political, intellectual, cultural and economic elites. Of course, in many ways, I cannot escape some of the privileged vistas of my own background - as no one can entirely escape the bent of their own lives. And yet, among my friends and acquaintances, as well as among various groups of "Yugosnostalgics" of my generation (people born in the late 40s, 50s and beginning of the 60s), there is almost a consensus regarding many aspects of the surreal, extraordinary, almost dreamlike quality of this "window" in time. Furthermore, my friends and acquaintances, whose written and oral memories ${ }^{4}$ I used here, were in no way privileged.

My privileged position and views result more from growing up among the intellectual elite of Belgrade, rather than the political or the economic elite. Although my father had been a member of the "CK" (Tse-Kha), the Central Committee of the Yugoslav Communist party for a short time in the late1940s before he was sent to a Political School in Soviet Union, he was removed from all political positions, after the breakup between Yugoslav and Soviet communist parties. It was only by a stroke of luck that did not end up in one of the Yugoslav concentration camps for political dissidents. Instead, the communist party removed him from its governing Central Committee and placed him to work in the Belgrade Historical Archives. By the end of the 50s, he became a professor of history at the University of Belgrade - leading mostly an academic and scholarly life. Similarly, my mother, who participated in the underground resistance movement in Belgrade, occupied by the German army during the WWII, started working in an organization that promoted wellbeing, care and culture for the very young children ${ }^{5}$, after the War. In the mid 60s, she too, became a professor at the University of Belgrade in preschool education studies. My parents socialized with people who belonged to the world of the educators, writers, poets, painters, musicians, actors and actresses, journalists, etc. There is no doubt that growing up in those intellectual and cultural elite circles, made my life very different from the majority of other children in Yugoslavia, and that it makes my memories, memories of a "privileged" person. Yet, these intellectual elites of Yugoslavia were also very different from the political elites of the Communist party officials, whose privileges also included great economic perks (e.g. greater salaries, large but cheap if not free of rent apartments, privilege of shopping in special stores always well stocked in all kinds of domestic products that may have been in shortage for the rest of the population, as well as having rare and greatly popular Western goods, reserved for the Communist party officials and their families, etc.), and probably some extent of being "above the law" (e.g. special tags on their cars that enabled them to park in restricted parking spaces, being able to "jump" the long lines in many bureaucratic institutions, etc.).

Every history, and particularly history based on personal memoires and narratives is dialogic. In the words of Abrams, "Oral history is a dialogic process; it is a conversation in real time between the interviewer and the narrator, and then between the narrator and what we might call external discourses or culture" (Abrams, 2016, p. 19, cited in Spaskovska, 2017, p. 16). One could add that it is also a dialogue between the narrator and the particular reader, situated within the past, present and future voices of all the involved people - both those who are remembered, those who are interviewed, those who do the narration and those for whom the story is told. As I narrate these stories, being both the interviewer and the narrator with a "privileged" point of view, I respond to the voices of my diverse dialogic partners. I respond to the

\footnotetext{
${ }^{3}$ Here I refer to a phenomenon called "Yugo-nostalgia," which "refers to a nostalgic emotional attachment to both subjective and objectively desirable aspects of the SFRY [Socialist Federal Republic of Yugoslavia]. These are described as one or more of: economic security, sense of solidarity, socialist ideology, multiculturalism, internationalism and non-alignment, history, customs and traditions, and more rewarding way of life" - Wikipedia, https://en.wikipedia.org/wiki/Yugo-nostalgia.

${ }^{4}$ Many of the written memories on which I rely are collected on a wiki we created to share these memories among a group of people who attended various cultural programs and summer and winter camps organized by "Dom Pionira Beograda" (Home of Belgrade Pioneers) - a cultural club for children and youth. The wiki can be found at http://jakljan.pbworks.com

5 "Društvo prijatelja dece" [Friends of Children Association] - http://www.prijatelji-dece-srbije.com/?pismo=lat
} 
friends and acquaintances whose memories I share both in participating in the same events, and as a member of "a generation" (Spaskovska, 2017), who would insist that this exceptional window in time-space provided unprecedented opportunities to "all of us," Yugoslav children and youth. I also respond to some of the co-authors in this special issue, who grew up in the Soviet Union, China and Czechoslovakia, and whose experiences in much more totalitarian societies, lead them to see me as "girl major key" (Мажор), ${ }^{6}$ one whose memories represent a very distorted picture, a view from a privileged bubble, blind for the suffering of the poor and the suppression of the ideological dissidents. I also respond to myself - to what I knew or didn't know at the times I describe, to what I believe and have believed that was not only my own personal truth, but the truth of many Yugoslavian children of my generation, and to what I now look with different eyes and with many questions. In other words, I am trying to discern the visible, the invisible and at the time intangible boundaries of a Golden Cage of my generation. Even just calling it a "golden cage", I am risking not only disagreements, but outright resentments from many of my friends and arguably from many others that I did not know personally. Not so much about the "golden" part of this image, but much more about the "cage" part of it. Not that they would deny the existence of the cruelties and autocracy of the communist regime, dangers of the political dissent, and hardships of common, non-privileged, people. Yet, what seems to dominate in the memories of many I talked to, are the internal freedoms and the opportunities that opened and enriched our lives. The internal reality of our cage was protective of our wellbeing. We experienced freedom in many areas of personal, academic and professional lives, we believed that we stood for justice, explored the truth, and were able to create ourselves and our own lives, despite the fact that the surrounding external world, that also shaped our childhood, was harsh, often brutal and did not really hold any of the high ethical principles and values in which we believed.

It is also true that not all Yugoslav children and youth had the same childhood. In Yugoslavia, the childhood I lived was not typical. In fact, Yugoslavia was far from being homogeneous in any way. Rather, the norm was in the diversity of people in every possible way and the tensions that accompanied these diversities: the circumstances and the localities of theirs lives (e.g., rural vs, urban), their multitude of ethnicities, their mutual political and ideological oppositions and enmities, etc. The various tensions would sometimes become visible and open; at other sometimes they were believed to be overcome, and at still other times these tensions were exacerbated, abused and played upon by those who were in power or sought power for ideological and other gains.

In this essay, I use a combination of a reflective auto-ethnographic method, a weak historical research and a strong intention to develop an "anti-methodological approach" (Matusov \& Brobst, 2013) to the memory of my own life and the lives of children and youth in the former Yugoslavia. In fact, in studying the times in which I grew up and my own ideological becoming, I wish to develop a research "mastery" (Matusov \& Brobst, 2013, p. 127), a "dialogic research art," where truth is conceptualized as living "in a critical heterodiscursive dialogue of diverse participants and communities with diverse foci, where alternative ideas are examined and tested by the participants - i.e., what Bakhtin called 'internally persuasive discourse' (Bakhtin, 1991; Matusov \& von Duyke, 2010)" (Matusov, Marjanovic-Shane, \& Gradovski, 2018 in preparation). My intention is to problematize, subjectivize, dialogize, even politicize my own and my close friends' memories and some historical analyses of the period.

Let me briefly explain. In my essay, I want to go further than, as Ngunjiri, Hernandez and Chang write, "...autoethnography is context-conscious. Rooted in ethnography (the study of culture), autoethnography intends to connect self with others, self with the social, and self with the context" (Ngunjiri,

\footnotetext{
${ }^{6}$ Eugene Matusov's comment on the margin, as he read a previous draft of this manuscript was: ", I think you should remember that you are a child of high level party functionary living in a bubble. In the USSR, children like you, [Ana], were called "boys major key" or "girls major key" (Мажоры) for their "too cheerful mood" and disregard of oppression and burden of the rest. wish you can listen to and understand Soviet underground song "Мальчики-мажоры": https://www.youtube.com/watch?v=6YVz1QDDloo
} 
Hernandez, \& Chang, 2010, p. 3). In Ngunjiri, Hernandez and Chang's view, this context is necessarily complex, multilayered and often brings in memories of the relationships among people with opposing views. However, I would like to go one step further in order to claim, like Abrams (Abrams, 2016), that memories and history are always dialogic, that they are contested and the "context" cannot be finalized by the presentation of an auto-ethnographic study. The very act of its writing and publication is an act of a transgression and a further leap into potentially risky transformations of the intersubjective dynamic. Even preparing to write this essay, interviewing my childhood friends and acquaintances, I encountered "different" contexts, opposing "realities" and diverse judgments of these "realities". I encountered changes in my own views and memories as well as in the views and memories of my friends. In that sense, I agree with Matusov and Brobst, that one of the defining differences between natural science and humanitarian science is the reflexivity of the latter, i.e. that the very fact of the research with people and about people usually changes the subject-matter of the research ${ }^{7}$. Furthermore, talking about our memories with my friends and acquaintances, was not a mere "collection of data" in any sense of the word, but rather, it was a profound personal and often risky ideological and political dance among us, former school buddies, forgotten sweethearts, people who grew together, and in some cases, also grew apart in many ways: geographically, culturally, ideologically, politically, epistemologically, even ontologically. Certain questions and certain answers raised open or silent new realizations about each other, new wonders and suspicions and lead to new judgments. This process made me aware that my essay not only could be contested, but that it potentially might cause personal hurts, new revelations and admirations developed in these "research encounters" rather than in revisiting some past "realities". Because of that, I am aware that in my presentation of the childhood I remember, I also answer to myself and to my own and my friends' relationships. This research incorporates "addressivity and responsivity" (Bakhtin, 1986). In other words, "not only humanitarian science texts report subjectivities of the studied people, but implicitly or explicitly they address these people and provoke responses from them" (Matusov \& Brobst, 2013, p. 127). That is why my essay is not merely an informative autoethnographic account, but it is also transformative project (cf. Lotman, 1988). First, it has been transformative for myself: doing research to prepare my essay and writing it, transformed who I was. Second, it has a potential to "become an event" (Bakhtin, 1999), transforming the relationships between me, my friends and unknown others, in further unpredictable ways.

\section{The background: trying to define my ideological origins}

Let me start with providing a short socio-historical-political overview of the Socialist Federal Republic of Yugoslavia, a country in the Balkans, that is no more. The years after WWII in Yugoslavia were turbulent and difficult. WWII in Yugoslavia was not just a war of the Yugoslav resistance movements against the German/Italian occupation. It was also a bloody civil war among the three main ethnic/religious groups: The Serbs (Christian Orthodox Slavs), the Croats (Catholic Slavs) and the large population of Muslim Slav Bosnians (or Bosniaks), as well as non-Slavic populations of the Albanians, Hungarians, Italians, Greeks, Jews, Roma, and so on. It was also a struggle for power and domination among the political and ideological factions: the Communists, Democrats, Fascists, Royalists, Liberal-Democrats, etc. The wounds they inflicted upon each other during WWII were still fresh and open, and, as the time will show, these wounds never completely healed, but were crudely patched over - only to open forty years later in the new civil wars of the 1990s that lead to the final breakup of Yugoslavia ${ }^{8}$.

I was growing up in the post WWII years, the time of unprecedented economic and industrial changes and migration from the agricultural rural to the industrializing urban centers. Most of all, the time

\footnotetext{
${ }^{7}$ In education, this is known as "Pygmalion effect" - that the very description of reality can change this reality: "when teachers' high or low expectations for their students can create self-fulfilling prophecies for the students' academic achievement and progress", (cf. Rosenthal and Jacobsen, 1969 in Matusov \& Brobst, 2013, p. 127).

${ }^{8}$ For a brief overview of the 1990s wars in Yugoslavia see: https://en.wikipedia.org/wiki/Yugoslav_Wars
} 
of my childhood was the time of huge ideological and political struggles under the Yugoslav communist dictatorship that forcefully and violently suppressed not only the non-communist opposition, but that was also purging any political and/or ideological dissent within the Yugoslav Communist party - especially punishing those who remained pro-Stalinists after the famous break between the Soviet dictator Stalin and the Yugoslav president Tito in 1948 (Shachtman, 1948). Thousands of political opponents were proclaimed "enemies" and imprisoned in the Yugoslav version of the Soviet Gulag - a set of concentration camps where they were tortured and many killed.

The lives of children in Yugoslavia were almost entirely planned and designed by the Communist government, especially through its Yugoslav Pioneer Organization and Association of the youth of Yugoslavia ${ }^{9}$. Although it was officially constituted in 1942 during the WWII,

"mass Pioneer organizations came into being after 1945 in Yugoslavia [like] in the rest of the Communist world-in the Balkans (Romania, Bulgaria, Albania), in Central Europe (Hungary, Czechoslovakia, Poland) and outside Europe (China, North Korea, Cuba). Pioneer organizations were created on the Soviet model. Their objective was to build up patriotic emotions and develop a sense of belonging to the ideological collective from the earliest age, [for the] enrolled school children aged 6 to 14" (Erdei, 2006, p. 1).

Prior to the break of Yugoslavia from the Soviet bloc, children's and youth's lives were controlled and "produced" with a full support of and ideologically almost identical to the Soviet model. As Erdei writes, "soviet influences were visible in every aspect of life, and particularly in a cultural and educational policy" (Erdei, 2006, p. 7).

What it meant was that the members of the Pioneer Organization (and those were virtually all school children), were systematically indoctrinated into a particular communist ideology. Children were

... considered pioneering builders of the future, who would move the society forward, finding new paths to socialist goals. Their whole upbringing and education, both in and after school, was created with reference to the Communist Party, under the supervision of ideologically and class conscious teachers and Pioneer leaders, who monitored and controlled the "correct" way of growing up. At an early school age (or even before that, as in Romania and Hungary) children were converted from the status of "ideologically undecided" to "ideologically decided" members of the community... (Erdei, 2006, p. 2)

However, after the breakup between Tito and Stalin in 1948, Yugoslav educators consciously worked on redefining the meaning of growing up in an ideologically "correct" way. Together with other "cultural workers", e.g. writers, journalists, film makers, theater directors and actors, artists, musicians, etc., people who worked with children started to invent a specifically "Yugoslav" childhood - based on political idea of self-management, psychological and social theories of human development as self-actualization, creative authorship, and on the idea of creating culturally and socially rich environments for children. "The transformation of the Pioneer organization into a "true children's organization" began in the same year (1950) as 'self-management' was established in Yugoslav companies. Along with the change in the content and method of work, the transformation also brought a change in the manner of social control of children. In the years that followed, a particular combination of 'merry,' 'childish' forms with serious, ideological

\footnotetext{
${ }^{9}$ Savez Pionira Jugoslavije I Savez Omladine Jugoslavije
} 
content was made. It created a way to control youth in a more indirect, informal and seductive, yet more innocent way—and one that was equally effective" (Erdei, 2006, p. 6).

Somewhat paradoxically, while the educators and cultural leaders were working hard to define a new "truly Yugoslav" communist ideology, that would still keep children's and youth's lives under their ideological control, they unleashed what amounts to unprecedented freedoms of creative authorial expression and exploration.

In order to get the reform going, a variety of activities for "correct creative development" and "encompassing personality" was to be set up with the necessary "material support." Newly planned children's activities would take place in specially created centers, and necessary symbols of the organization, plus now toys, books and magazines, would be supplied as soon as possible. Beyond the Pioneer corners and Pioneer residences, "Pioneer cities" were built near Belgrade and Zagreb, and a Pioneer valley near Sarajevo. Playgrounds were also supplied with equipment required for proper physical training. The world of children/Pioneers was gradually institutionalized in activities and content. Special Pioneer summer houses were built, Pioneer holidays set up, Pioneer magazines and radio stations founded, a "Pioneer railway" was created, and a later renowned child-orientated event called the Yugoslav Pioneer Games was organized for the first time. Artistic creation for children was stimulated (children's literature, children's movies), and children by themselves were encouraged to engage in different art forms.

This new cultural and educational sensibility for the child was developed in times of Yugoslavia's growing economic and political opening toward both the "non-aligned" world ${ }^{10}$ and the capitalist West ${ }^{11}$. Paradoxically, while striving to define a "true Yugoslav" ideology, brought to life possibilities and freedoms that did not exist in other more dogmatic communist countries of the Soviet bloc.

Thus, I can claim to be a part of a special intellectual and cultural elite that supported and was supported by the Yugoslav Communist project on the ideological, cultural and political scene of the country. However, my life and the lives of others similar to me were not secluded from the other children of Yugoslavia. We did not have special schools, or special clubs, nor did we go to special resorts, reserved only for the elite. We lived in the mixed neighborhoods and went to the neighborhood schools to which our "address belonged." The cultural organizations, playgrounds and events for children, we attended were all functioning based on the freedom of attendance, e.g. "walk in" basis. Except when very young, below 7 years of age, children used public transportation to travel through Belgrade, or walked around. Many of my childhood friends were people from "ordinary" families, who did not belong to the communist, intellectual or cultural elites. Their families were most diverse: people who came both from the riches and from the dire poverty; with jobs ranging from physical workers, who loaded freight trains or were "cleaning ladies", to doctors, engineers, artists, or private tailors and seamstresses, hairdressers, or bank clerks, school teachers, professors, opera singers, medical doctors, accountants, etc. Their families were of all six or more nationalities that lived in Yugoslavia. I can't think of any rule to systematically exclude some children from the life I remember as mine. I can find only probabilities that gave some of the children more chances than others to live in the golden cage. First, it was more probable to be exposed to and become a part of our rich and protected children's culture - if one lived in an urban center rather than in a village or a smaller provincial town. This was true especially if one lived in Belgrade (the capital), but also in the big centers of

\footnotetext{
${ }^{10}$ The non-aligned countries included among others the oil-rich Middle-Eastern countries where Yugoslav engineers started working on big energy projects, and many African states with which Yugoslavia started building joint economic projects.

11 "Tito used the estrangement from the USSR to obtain US aid via the Marshall Plan, as well as to found the Non-Aligned Movement, in which Yugoslavia was a leading force." Wikipedia, https://en.wikipedia.org/wiki/Tito\%E2\%80\%93Stalin Split
} 
other regions, Sarajevo, Zagreb, Ljubljana, Split, etc. Second, it was more probable that one would be more included if their family was not hurt by the ideological and political oppression of the time. And yet, some of my acquaintances were children of the known dissidents who either fled the country or served time in prison $^{12}$.

Against a tumultuous political and economic background, I was growing up among children who were supported and encouraged - through a host of cultural programs, cultural centers, special trips, summer and winter camps, etc. - to develop their interests, passions and creativity. These programs were organized as a part of the overall Yugoslav initiative to support children and youth. Youth was "seen as a critical pillar of the Yugoslav socialist project, the state invested in the youth both symbolic and economic capital with the hope that the sense of 'Yugoslav socialist patriotism' would supersede and replace narrower circles of belonging or ethnic and class divisions" (Spaskovska, 2017, p. 38). This enabled us to gain progressively growing freedoms and access to the world cultures. Besides several non-governmental organizations like the "Association of the friends of children," which organized cultural programs for younger children, Yugoslavia developed a "relatively liberal youth culture and a semi- free press, ... [and by the 1980 s] the youth media [were used] as an arena for various articulations of demands for freedom of speech and critical reflection on the contemporary socio-political reality" (Spaskovska, 2017, pp. 38-39).

Our protected and promoted lives, in many ways stood in sharp contrast to the otherwise authoritarian political, economic and educational regime of Yugoslavia. This authoritarian nature of the "official regime" of Yugoslavia was not unknown to us (especially when we became teens), and our lives were not entirely without the clashes with "the system" - clashes both in the contradiction of our own values and in the actual events of rebellion against the authorities.

Maybe the existence of such parallel yet contradictory realities was possible because Yugoslavia was a country, "in between"13: between the Occident and the Orient; between the democratic capitalist West ${ }^{14}$ and the totalitarian socialist East; between the rich developed world and the poor "third" world. Maybe it was this position of being "in between" that created openings and loopholes in every aspect of Yugoslavian life. Whatever the causes, I want to explore these loopholes in the socialist regime that enabled a group of enthusiastic idealists and educational activists in the generation of my parents to create a world for Yugoslav children, which, in the hindsight, and from any outsider perspective, must seem outlandish, unreal, almost impossible.

Here, through my and some of my childhood friends' memories I provide descriptions of a few programs and institutions that existed as ubiquitous cultural environment for and with children and youth. These programs took place in the cultural centers and youth clubs in Belgrade, where we experienced the magic smell of oil paint, created self-styled music groups, acted, directed and experimented in our theater and film projects, organized and participated in reading clubs, wrote poetry together, marveled at the first cartoons we ever saw, and became insatiable watchers of films and TV. Some of my most significant memories are of life we created in the summer and winter camps spent away from our parents, on an island in the Adriatic Ocean and in the mountain Tara in Serbia.

\footnotetext{
${ }^{12}$ Notably, the son and daughter of Milovan Djilas who was one of the most worldly known Yugoslav political dissidents, serving a jail sentence in a Belgrade prison.

${ }^{13}$ This is also the title of a movie by a well-known Yugoslavian film director S. Karanović - see an excerpt here: "In between" ("Nešto između," 1983)

${ }^{14}$ Yugoslavia was a recipient of the "Marshall plan" and other funds from the United States from 1949 to 1989 (according to Lampe, Prickett, \& Adamović, 1990)
} 
And yet, our freedoms, our riches, our relationships and adventures, events and programs we made, had both visible and invisible "socialist" boundaries. I use the "socialist" in quotation mark, as I will try to show through the memories of our lives - that it was a mixed bag of contradictory and clashing values: simultaneously valuing freedom, creativity, agency and activism, on one hand; and, on the other, following authoritarian, hierarchical, monologic and finalizing principles of an ideology we were not supposed to question, an ideology that produced "the most developed form of society" - our "emancipated and the most advanced country" - Yugoslavia.

We didn't always feel those cold, unforgiving, and sometimes dangerous boundaries, but we still knew that we lived within a golden cage. Our freedoms stopped sometimes gently, without our suspicion, but sometimes openly, roughly and with a reprimand. We rarely noticed (as children) the soft captivity of our ideologically homogenized official socialist school programs and textbooks that painted our motherland non-problematic and glorified: only as loving, beautiful, sunny and gay, a place where all the problems were solved and all the people were ready to help each other in harmony, unity and brotherhood. But, we also sometimes experienced the limits that bound down our freedoms and creativity, when we were "put in our place", our voices silenced, and we could glimpse the ugliness of the reverse side of our "freedoms". We would, from time to time, whisper about friends whose father or mother were dissidents, some of whom have even been on "Goli Otok"15 or have "mysteriously disappeared" without any trace or explanation. We were aware that certain things should not be talked about without special precautions ${ }^{16}$ taken so no unwanted ears could hear them. We knew that all our public work might be subject to censorship.

Here I make our curious and surreal golden cage live one more time through the stories about our everyday lives, relationships, small and big joys and miseries, and through the mundane and heroic quests and brushes with the "law and order" of the Yugoslav "in between" regime.

\section{The boundaries}

The 50s in Belgrade was the first new decade after WWII and the memories of the war were fresh for my parents' generation. They were palpable in every moment of our lives. I remember a neighbor, Sava, a woman with one leg who walked on crutches. She lost a leg in the War. The time was divided between "before the War" and "after the War". Everyone had someone in their family who was lost or killed or wounded in the War. For my mother, the story was about 56 family members who perished in the Holocaust, especially her beloved 7-year-old cousin. But the overpowering post war energy and jubilation were present in every life detail. "We fought for you, so that you can live a better life and be free!" - were the words we heard daily, present in every deed of our parents. Somehow, for me the life began not at the time of my birth, but with the Liberation and Victory at the end of the War. And then one more time, with the Yugoslav liberation from the clutches of the Eastern Empire, with the break between Tito and Stalin ${ }^{17}$. It was the dawn of the new world: the dark shadows of the German and Russian totalitarianism were lifted! ${ }^{18}$ Everything was in the hands of our parents and their friends and comrades, people who were our shield from the evil, who protected us and knew what the best was. Their leader was Tito - a hero who lead the resistance and battled the enemy throughout the War, who was chosen for a leader of the communist party and elected

\footnotetext{
${ }^{15}$ Goli Otok was one of the harshest and most known of the concentration camps for the political prisoners in Yugoslavia, until the mid 80s. See more here: https://hr.wikipedia.org/wiki/Politi\%C4\%8Dki_logor_Goli_otok

${ }^{16}$ For instance putting the phone under a pillow inside a closet

17 Josip Broz Tito was the head of the Yugoslav Communist Party and "the eternal president" of Yugoslavia until his death in 1980. Joseph Stalin was the communist dictator of the Soviet Union, until his death in 1953. The famous Tito-Stalin split occurred in 1948 - with growing political disagreements between the two leaders and culminating in the Yugoslavia's expulsion from the Communist Information Bureau (see more: http://www.thenagain.info/WebChron/EastEurope/TitoStalin.CP.html)

${ }^{18}$ Of course, as my colleague, Eugene Matusov pointed out, there were also dark shadows of Yugoslavian totalitarianism 1948-1965, where, according to the growing sources 20,000 people died (or were killed) in and 250,000 went through the Yugoslavian concentration camps during that time. See for instance, (Cvetković, 2011; Kotek \& Rigoulot, 2000; Savich, 2007).
} 
for the first president of the new socialist Yugoslavia in 1945. We believed in Tito and loved Tito, with a childlike trust in the omnipotent and good parent.

The majority of the children were initiated into their socialist childhood through the ceremony of becoming a Pioneer, also called a Tito's Pioneer, when they ceremoniously received a red scarf, a Pioneer emblem and a "pioneer's cap" with a shiny red star, and where they collectively recited the Pioneer's Oath.

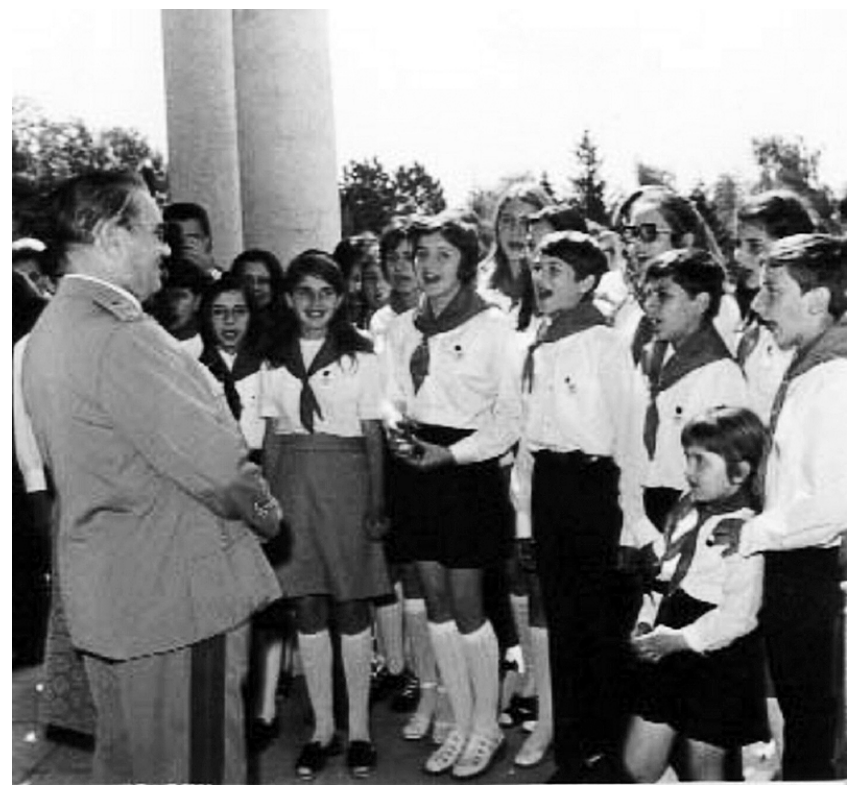

Tito and the Pioneers
Pioneer's Oath

Today when I'm becoming a Pioneer

I give my honorable Pioneer word

That I will diligently learn and work

Respect parents and teachers

And be a faithful and honest friend

Who keeps his word of honor;

That I will follow the path of the best Pioneers,

Appreciate the glorious deeds of Partisans

And all progressive people of the world

Who stand for liberty and peace;

That I will love my Homeland

Self-managing socialist Yugoslavia

And its brotherly nations and nationalities,

And that I will build a new life,

Full of happiness and joy.

However, I mark the boundaries of my socialist childhood, the entry and the exit from it, with two very personal encounters with Tito. With the first - I became a Tito's pioneer, and with the second, I finally broke with Tito, bewildered and disgusted, but without regret, for the first time seeing the paradise of my childhood from the outside-in, as a golden cage.

I met Tito in person on, what was known as Tito's Birthday, May $25^{\text {th }} 1959$, at the end of my first grade. I knew Tito, of course, from the pictures in our textbooks, from the big canvases draping buildings at the times of holidays and parades, and from his speeches on the radio. I somehow believed that my father knew Tito personally and that they held daily conversations about how to make our country better ${ }^{19}$. "Building our country for a better life" was the most important thing and the highest ideal, and we lived it in everything we did. Tito's birthday, May $25^{\text {th }}$ was celebrated un Yugoslavia as a holiday known as "The Day of Youth". On that day, a great performance-rally had been organized in the one of the biggest Sports Stadiums in Belgrade ${ }^{20}$. The program featured speeches, songs and dances performed by children and youth dressed in different colorful costumes, making intricate symbolic figures with their bodies. Even the audience on the other side of the stadium, facing Tito's special spectators box participated in making

\footnotetext{
${ }^{19}$ My father was a member of the Communist party as a youth in the pre-war Yugoslavia. During the war, he joined the "Partizani", the communist resistance movement (https://en.wikipedia.org/wiki/Yugoslav Partisans). After the war, he spent about a year in the Soviet Union in a political school, but came back in August 1948, with the break between Tito and Stalin. For a short time, he was a member of the Central Committee of the Yugoslav Communist party. In 1950 or 1951 he became a director of the Historical Archives of Belgrade, and from 1963, he was a professor of history at the University of Belgrade.

${ }^{20}$ Dan Mladosti. See a video excerpt from the 1979 celebration rally here: https://www.youtube.com/watch?v=ig6fuoDL_Lw . The words of the song's chorus represent a slogan famous in the communist Yugoslavia: "Narod, partija, Omladina Armija," meaning "The People, the Party, the Youth, the Army" (as four pillars of the Yugoslav society).
} 
different slogans raising different color-coded tablets. The program culmination was the arrival of a young man or a woman carrying a baton filled with birthday greetings and good wishes collected during a monthlong relay-run throughout Yugoslavia. This baton was carried over the stadium and up the stairs to Tito, a guest of honor.

That year, 1959, when I was in the first grade, our class was chosen for a special task: we were to be the "pioneers" who would throw flowers to carpet the bridge as Tito walked over to his box on the top of the stadium. "Pioneers" was an organization of communist children, styled partly on the images, ideas and values of the American scouts (with its values of discipline and exploration, open air adventures, health and exercise) and partly on the images and values of healthy and strong youth developed both in Germany ${ }^{21}$ and in the Soviet Union ${ }^{22}$.

We were told to stay in our rows along the bridge rails, and only to throw the flowers under Tito's and his guests' feet. As we stood there, I suddenly had an idea! I had a beautiful yellow rose in my hands and, in the spur of the moment, I decided to personally hand it to Tito, rather than to throw it down under his feet. So, as Tito approached me, I ran out of my line and stood in front of Tito offering him the yellow rose. He was surprised, but he bent down, took the rose from my hand and offered me his cheek to kiss him. I still remember a large brownish spot he had on his elderly skin, and I remember being delighted and feeling very special. Although I already knew that I was that child for whom Tito and my parents fought the War to have a better future, I count this event as my symbolic entry into the golden and heroic life of the special young people, the "pioneers". The entry felt sunny and shiny, and made me feel important, accepted and good.

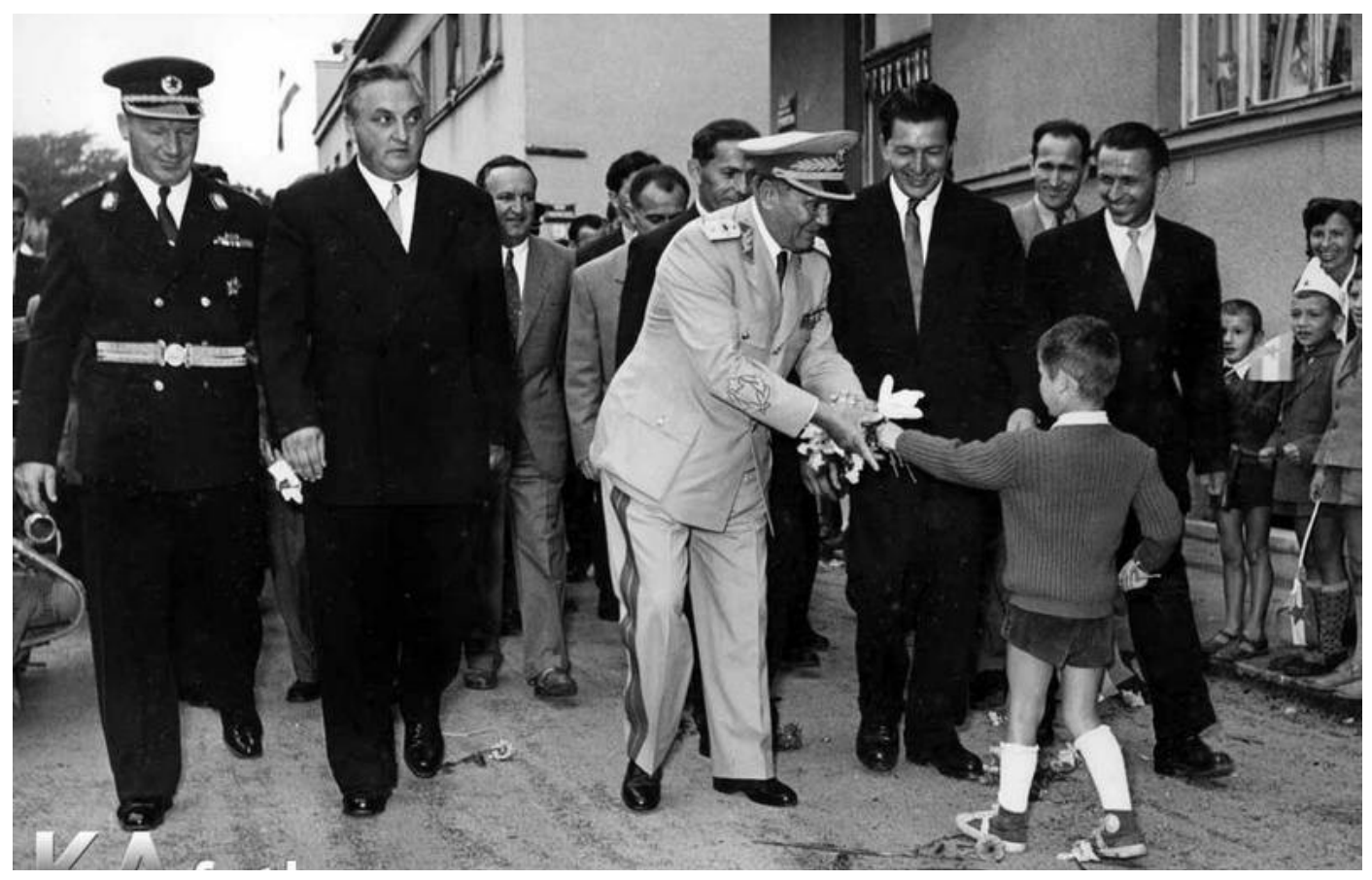

A pioneer gives Tito a flower on May $25^{\text {th }}, 1955$

\footnotetext{
21 See for instance the famous 1925 movie by Kaufmann and Präger, "Ways to Strength and beauty" https://www.youtube.com/watch?v=ls-DVyr1uXY

${ }^{22}$ Komsomol - https://en.wikipedia.org/wiki/Komsomol
} 
For me, the exit from this golden life happened just ten years later, although at the time I felt those ten years as "the whole life" - a difference between being a child of seven years old and a young adult of seventeen. It happened during a speech Tito addressed to "us," the Belgrade University students ${ }^{23}$, broadcasted on Belgrade TV. Tito's speech, ended the students' protests. To understand what happened that spring 1968, you have to know about the students' movements in Yugoslavia. 1968 was a culminating year of the students' protests and uprisings throughout the Western Europe and the USA ${ }^{24}$, but not a lot of people outside of Yugoslavia knew that a similar movement happened in Belgrade, and that other bigger cities and towns in Yugoslavia were on the verge of experiencing similar protests. Without going into the historical details ${ }^{25}$, it was a time of disillusionment, of the growing feelings of betrayal of the socialist values the children and youth in Yugoslavia were taught to believe in - equality, liberty, democracy, selfactualization and self-determination, honesty, responsibility, and so forth. In Yugoslavia, our protests, resonated with the slogans of other youth and students' protests around the world. We were demonstrating against the growing corruption in the socialist regime, hypocrisy, loss of principles, liberties and human rights, and the growing sense of loss of the democratic rights, freedoms and socialist ideals. Tito's speech came like a bucket of cold water over my head, after the heated and boisterous ten days in which we, the students, occupied Belgrade University and proclaimed it "The Red University Karl Marx". Within a courtyard of the "Filozofski Fakultet"26 surrounded by police ready to storm in, our professors joined us, together with the many Belgrade's cultural celebrities: writers, actors, film directors, musicians, philosophers, you name it. Speeches were held, full of support and praise for our efforts and courage to stand up to the injustices everyone could see - poverty, job losses, corruption, even blatant undisguised, unpunished embezzlement, etc. One of the most memorable speeches was given by a very known actor inspired by Robespierre's speech to the Jacobin Club known as "Report on the Principles of Political Morality"27:

Our eyes were open, we saw how the enemy prepares and rises, but we didn't give a signal. We let the people to guard and watch themselves. But the people did not sleep! The people started clinking their arms! ... The weapon of the Republic is - fear! And the power of the Republic - virtue! Virtue! Without virtue, fear would be deadly! Fear! Because without fear, virtue is powerless. They

\footnotetext{
${ }^{23}$ Although I was still in high school, I joined with the Belgrade University students and actively participated in creating and distributing flyers, which described our views of the political and economic troubles in Yugoslavia, and called people, especially the workers, to join us in our demands for democratization, end of corruption, raising of the impossibly low minimum wages, and making the centrally planned economy more open for the initiatives that would create more jobs, etc. Interestingly, although I did not go to school for the whole 10 days, my high school teachers who knew what I was doing, never asked me nor my parents to bring a note that would excuse my rather long absence.

${ }^{24}$ See a brief overview here: https://en.wikipedia.org/wiki/Protests_of 1968

25 There are many reports of what happened in Belgrade in the first 10 days of June 1968, and they are still controversial and passionately colored with the reporters' ideologies and beliefs. Some call it leftist, some liberal bourgeois, some see it as utopian and unrealistic, others compare it with the students' protests of the later years in Belgrade, etc. For those who can read in Serbo-Croatian, here are some interesting links (selected almost randomly): http://www.novosti.rs/vesti/naslovna/reportaze/aktuelno.293.html:216610Belo-usijanje-crvenog-univerziteta,

http://www.vecernji.hr/hrvatska/tito-1968-hapsite-ja-ne-pregovaram-841553

http://elmundosefarad.wikidot.com/1968-godina-cetrdeset-godina-kasnije-dragan-klaic

http://www.glassrpske.com/novosti/vijesti_dana/Studentske-demonstracije-u-Beogradu-1968-godine-Udaljavanje-odideala/lat/155345.html

26 "Filozofski Fakultet" is comprised of the Departments of Philosophy, Sociology, Psychology, Education, Archeology and Classic Languages - and it resides in the oldest University of Belgrade building - Kapetan Mishino Zdanje - built in 1863 - see it here: https://upload.wikimedia.org/wikipedia/commons/c/c6/Kapetan Misino Zdanje.jpg

${ }^{27}$ See the translation of that speech here: http://www.indiana.edu/ b356/texts/polit-moral.html
} 
say that fear is a weapon of a despotic reign and that, because of that, our reign looks like despotism. Of course! A revolutionary reign is the despotism of freedom! Freedom against tyranny!28

We believed that we could bring back revolutionary ideals of socialism and communism and restart our country's development along the just and responsible human socialist values. But as I listened to Tito's speech and as I was becoming aware of the students' cheers and the songs of the renewed loyalty to Tito and socialism, I froze with a sudden chill and realization of how manipulative Tito was and how demagogic, dangerous and treacherous were his words. Although he said almost everything that a great defender of the human rights and liberties in socialism should say, as he tried to play every important chord in our hearts and minds, it all sounded hollow, false and hypocritical to me:

The young people's revolt came spontaneously, but it was infiltrated by diverse, to us foreign, elements, who wanted to use it for their own goals... However, I came to a belief, that a vast majority, I can say 90 percent of the students are just the honest youth, of whom we did not take good care, whom we saw as mere students whose time did not yet come to be a part of the social life. We must correct this error. The events in Belgrade have now hit many of us... [The Yugoslavian students' demonstrations] were not influenced from abroad... Students' demonstrations reflect our own weaknesses that have piled up and that we must now eliminate. ${ }^{29}$

As I listened, I could feel the lies, I could see through this double-speak. And I realized that our lives, so free, liberated and creative, so authorial, confident and full of initiative, that our "better life" - was somehow a giant lie. I saw regret that "they didn't take a good care", I guess, in making our lives less free and more in line with "them" - the party leaders. I realized that we were told that we could be safe and maybe even continue to believe in all the ideals we grew up with, only as long as we stayed put in our own small childhood worlds where "they" "took care" of us, and only as long as we stood out of the way of "their" important "adult" matters. Tito was not merely patronizing us, which was insulting in its own right, but his speech was laden with skin deep threat: "just do not actually meddle into the politics and power, just stay in your place, and you'll be all right". Yet, I watched with a feeling of shame how my comrades, the students, cheered and danced, and I could not understand why and how they did not see through his demagoguery. Subsequent months and years proved that my gut feelings were correct, that not only nothing had been done about human rights, democratization, freedom and economic development, but that the regime was becoming more overtly totalitarian, striving to punish and isolate everyone who took part in those protests - from the professors of the university to the student leaders. I count that day, the day of Tito's speech to the students in June 1968, as the day when I stepped out of my golden cage, and saw the ugly side of the regime that made my childhood so good, so right and so true ${ }^{30}$.

\footnotetext{
${ }^{28}$ (Parts of the speech by Stevo Žigon, reported by Popov, 2008)

${ }^{29}$ An excerpt from Tito's speech on June 10, 1968. My translation from Popović (2008). This same excerpt from the actual speech is here: https://www.youtube.com/watch?v=Nne2feNUEu8

${ }^{30}$ Only fifty years later, in 2008, one could read about the planned manipulation, disrespect and dangerous background of Tito's speech. Tito's first impulse was to brutally arrest the leaders... Only after several long meetings with the police and with the other communist party leaders, he decided to diffuse the situation with a speech on TV. According to the minutes from a meeting with the party leaders a day before his speech, Tito allegedly said: "I would not address only the students, but all the youth and the workers, too. I would tell them nicely, listen, young comrades, you should have a trust that we are taking care of the whole Yugoslavia, of the working class, of all the youth. We are taking care of everything. I will tell them that they have to change their views and not be fooled by these various elements. And I will demand that they start to work, after all" (Despot, 2008)
} 


\section{A culture for and by children}

If you ask people of my age who were growing up in Yugoslavia right after WWII, about their childhood, you may hear stories that may sound too good to be true, or too mysterious and fantastic to be true, or too bold to be true, or even too funny to be true. Many of these stories for me and my friends come from our hanging out in "Dom Pionira Beograda" (Home of the Pioneers of Belgrade) - a cultural center for children and youth. We could just walk into the Dom Pionira, at any time when it was open, and it was always open from my point of view - on working days and on the weekends, sometimes to the late at night, for some special film viewings, poetry readings, guest speakers, etc. My friends and I began to write our memories ${ }^{31}$ of the various "clubs" and "groups" where we got involved in art, music, film, poetry, theater, sports... Our clubs and our joint participation in many activities were pivotal for the lives and careers of many who later became renowned artists, actors, writers, designers, journalists, scientists, etc. For instance, one of my friends, today a painter, a photographer and a graphic editor of a major news magazine for children in Belgrade, remembers,

I started the first grade that year [1956], [...] and I don't know why or how, but [...] the building of "Dom Pionira" [...], was much more attractive to me than my school. [When I entered for the first time, I saw] several doors, and each leading to a "section" (a club). It just happened that I stepped into the art atelier. I came alone and I was shy, but Shana [the art teacher] was there in some sort of a green overall (years later, when I was an adult, I saw something similar on the surgeons in the surgery halls, and I remembered...). There were two big Ping-Pong tables covered in drawings, sheets of white paper, tubes of "temperas", a bunch of big (or so they looked to me) and even bigger brushes, and enormous glass jars full of water (I still have such a jar in my basement, but I keep pickles in it). In the corner of the room was a sink where I washed the brushes and the giant water jars.

I used to draw "stiffly" - "hard", as they used to say. Shana would tell me:

- $\quad$ Not this way! Push the brush over the paper! Wider, EXPRESIVELY!

I never heard that word before.

Her husband, a well know graphic artist at the time, said to her: "Let the child do what he does! See, he has a hard, stone hand - he will become a graphic artist!'32

Another friend, now a movie director, remembered directing the first movie we, the children, filmed in our summer camp,

Once, when we were filming, the scenario called for eating ice cream. We kept repeating this sequence many times, pretending that we had "technical problems", [but actually, to have a legitimate excuse to eat more ice cream]. But when our first movie became a great hit [in the festival of short films in Belgrade] ... the smirk dropped off from the faces of the adults [who supervised us]." ${ }^{33}$

The highlight of our lives, beyond doubt, were our summer and winter camps spent away from our families and schools. Our summer camp was on a small uninhabited island in the Adriatic Ocean, Jakljan ${ }^{34}$ [Yaklyan], near Dubrovnik in Croatia. The closest human dwelling, reachable only by a boat, was a village on the nearest island of Shipan. The first several years (starting in 1958) there was only one building, a villa

\footnotetext{
${ }^{31}$ We now have a Wiki space - http://jakljan.pbworks.com where we publish these memories and keep "our" old and new photos.

${ }^{32}$ D. Glušac, "The art atelier of Dom Pionira Beograda"

33 Srdjan Karanovic, 1962, from: "Secanja starih clanova Doma Pionira Beograda".

${ }^{34}$ You can see a picture of our "old house" here: https://www.flickr.com/photos/jakljanci/263516170/in/album-72157594317478782/
} 
built by the former owner of the island, someone known to us a "Herman". We slept in that villa and in the tents pitched in a nearby olive and pine grove.

On Jakljan, we created our own society and culture. It was a peculiar blend of very institutionally structured, regimented social order, with various hierarchies of ranks and positions, and very creative, artistic, literary, performing and sports activities. We were organized into "groups", mostly by age and gender and assigned to the rooms (or tents) where we slept. Each group elected a leader, who would represent the group in the "pionirski shtab" - the pioneer headquarters, our central governing body, something like an elected senate. The "shtab" members selected the "president," and various "ministers" for the cultural life, for hygiene, for the sports, etc. The "shtab" meet each evening to decide the "daily ordinance" for the next day. This included making the daily schedule of activities for the next day, hiving special honors to some groups and the choice of the "pioneer of the day" - a child honored to raise and lower the (Yugoslav) flag on the mast during the morning and evening assembles.

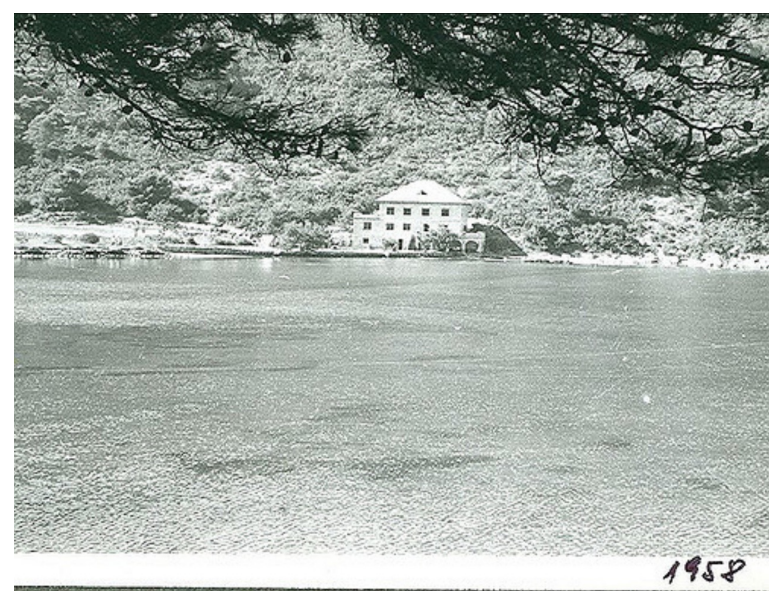

Postcard home:

Dear Mama and Tata, we came to Jakljan.

By boat they call it a cruiser.

I jumped from the cruiser in the Jakljan bay and.

Swam to the shore together with the biggest boys' teacher. Drugarica ${ }^{35}$ Gara brought my backpack to the land I am in. A room with five girls.

Love, Anchica ${ }^{36}$

Jakljan - the old building

The groups were always competing in various activities by getting "points." For instance, we cleaned and tidied our rooms. A special "hygiene" committee inspected them every morning giving points for the cleanliness, order and beauty. Many other activities could "earn points" for a group. I remember getting "points" for killing wasps, during an action of wasp extermination - one point for 10 dead wasps killed by clapping two Ping-Pong racquets together, or by drowning them in jam. The wasps were pervasive at the start of each summer - swarming and clinging to the bowls of jam at breakfast, buzzing around our water pump (the main water source on the island), and it was not a rare occasion that someone got stung.

The group points were summarized every three days and a group with the most points would be honored by letting it chose a "name," instead of being called by a number (the "first", the "second" etc., group). We chose the names of heroes, most often of legendary resistance fighters from the WWII, sometimes a dead poet, scientist, etc. It was an honor to bear a name of an important person. That was

\footnotetext{
35 "Drugarica", female form of "drug" - comrade. Way to address people, comparable to Miss or Mr.

${ }^{36}$ A postcard I sent home. My idea of a sentence was that each starts with a capital letter at the beginning of a line and ends with a period at the end of the line. My teacher, Gara added on the side: "Anchica is well. She is a good swimmer, staying in the water like a fish sometimes the whole morning. Your Gara", July 1958
} 
our only reward for the hard work of "getting points." It was an acknowledgement of how worthy we were as individual children and as a group.

Besides these age and gender groups, we were also grouped by our swimming skills. These were tested at the start of the camp each summer, and we would wear colored wrist bands - coded by the level of our swimming skill: white - for a non-swimmer, then light green, then blue, red, and the best, red-andblack. I, of course, always had the red-and-black band. It was my pass to all the beeches and to all swimming and diving activities, something I enjoyed doing. There were always a few PE teachers in the camp, coaching us in swimming, diving, and other sports. Their goals, so we thought, were to care for our health and our growing bodies that should develop into healthy and strong "socialist" people. One of such "health concerns" of our PE teachers were flat feet, that, according to them, were an epidemic among us, urban, sedentary, children from Belgrade. To prevent and/or cure our flat feet, our PE teachers encouraged us to walk barefoot. Not only that! Under their supervision, we made a training course that we called "the path of death". It was about 30 feet long trench filled with small sharp stones. We had to walk or run on the "death path" as part of our morning exercises (mandatory for all).

From the time Jakljan was founded as a summer camp in 1958, we, the children and youth, started to "build" it. In 1958, when we first came, the "old house" was the only house apart from a ruin of an old chapel from the medieval times when the island was a leper colony (as we were told). In the first few years we had no electricity, save for a few hours each evening when the electric current was produced by a diesel fueled generator. There existed a decrepit, partly ruined quay, where even a small boat could dock only by lifting its motor out of the water. And there was a sand quarry, used sporadically by the building companies from the main land, sending from time to time a large and slow, freight boat - a trabakula ${ }^{37}$ - to haul it. Over the years, we started building various structures. Every year we had "Work actions"38- building projects to improve our island - fashioned after the Yugoslav young adults' work actions ${ }^{39}$. Over the years, we have built a new docking quay, probably three times as big as the original half-broken one; we built a long walkway quay around the whole bay; we built two concrete paths connecting the "New Building" and the bay, etc. "Work" was one of the highest values of our small island society, as it was for the socialist culture of the whole Yugoslavia - the so called "cult of work" (Dobrivojević, Duda, Mihelj, \& Panić, 2014). Although by the time I was a young child this kind of work - in work actions - was not any more mandatory (like in

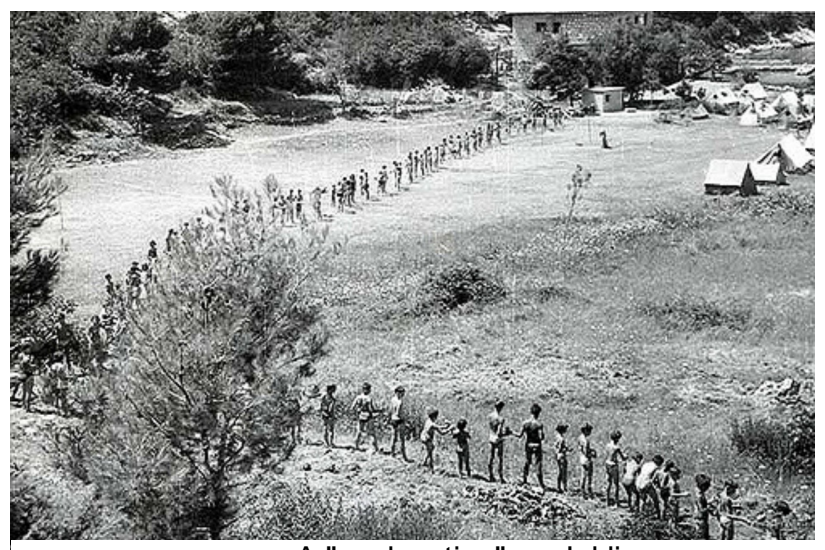

A "work action" on Jakljan

\footnotetext{
${ }^{37}$ A trabakul (trabaccolo, Italian) is a type of Adriatic Sea coaster with two masts, each with a main sail. It is a cargo vessel. (https://en.wikipedia.org/wiki/Trabaccolo)

${ }^{38}$ See a picture of one of our work action here: https://www.flickr.com/photos/jakljanci/263511252/in/album-72157594317478782/ In the long line that zig-zags across the field, we are passing stones from the quarry to the structure we are building.

${ }^{39}$ See more here: https://en.wikipedia.org/wiki/Youth_work_actions
} 
the years right after WWII, and in some other socialist and communist countries), and probably just because it was not mandatory, we - the children of Jakljan - were so proud to be building our island, that working as a builder was regarded as one of the highest honors. It was, in fact, such an honor that we "fought" over our tools! We did not have enough tools (shovels, hacks, picks, etc.) so those who would secure one, jealously kept them, tried not to let go of them. I remember going to swim with a shovel, even going to sleep with a shovel.

At the same time, and within this socialist regimented organization, our lives were also full of imagination, laughter, games, fun, love, excitement. The second summer I went to Jakljan (I was 8, almost 9 years old), I secretly fell in love with "M". It happened that we soon held our "Partisan night" - a special game we played for one designated whole night! It was a game of strategy, skill, daring and deception. There were two teams: "we" - the children of the camp, and the "enemy" - about 10 of the oldest youth in our camp. "We" had to guard and preserve our flag, neatly folded and placed on a bench next to the mast in the middle of a large field. The "enemy's" job was to steal our flag. We planned our strategy for several days in advance. Our enemies, secretly from us, also planned their "attack." After dinner, all the lights on the island were turned off. The darkness was deep. Throughout the night, we waited for our turn to guard our posts in the utter darkness, hardly daring to whisper to each other. Some of the smallest children fell asleep. Each half hour or so - it felt like ages to us - a member of the shtab (our commanding headquarters), holding only a dimmed flash light, would quietly take a child by the hand and lead her/him to a designated post. The rest of us did not know when our turn was coming, where our post will be, with whom will we be paired, nor whether we could rely on our "pair" to protect us in this darkness. We hoped to find out more from the kids who returned - but they were not supposed to "talk"! The wait was long. I lost the count of the children who were already posted and returned. I lost the count of the minutes and hours. I almost fell asleep. Suddenly, they came for me. She took me to the farthest and the darkest post that existed. It was the post in front of the old "chapel". A fleeting thought that there may be ghosts there crossed my mind. How foolish, I thought to myself - there are no ghosts! When we arrived to the plateau in front of the chapel I found out, what a surprise!, that I was paired with "M"! I was mesmerized. He was my "knight", my "sympathy"! We were given the rules and a "password." If anyone was to approach us - we should ask them for the password. If they did not know the password, a-huh! We were to immediately "arrest" them as the enemy - and call our patrols to take them "out of the game". The two of us were left alone, in the middle of the woods, in front of the chapel, in almost total darkness! It must have been midnight, or close to midnight - a mysterious hour. I can still feel the shivers of the thought! What would I actually do if I saw a ghost? We, the two 8 year olds, stood there, spooked and silent in the scarce light of the stars and a sliver of a moon. "Don't worry, I will protect you, Anchi!" said "M". But, in spite of the darkness, I heard trembling in his voice. It suddenly occurred to me that he might be more afraid than me, and that it was I who should protect him. For some reason, I suddenly felt a relief and a surge of a razor-sharp determination, control and coldness. I was on a mission now, and I was going to "arrest" whoever came here and didn't not know the "Password", after all. Bring them on! Suddenly, the nearby bushes started to shake. I yelled: "Who is there?", "M" grabbed hold of my hand. I thought that he did it because he was afraid and turned to me for protection. I yelled one more time "Who is there? Say the password or you cannot pass!" But nothing. Not a sound, not a shiver. We stood there trying to discern, in this darkness, a silhouette of a person, a darker shadow among shadows. But nothing. Not even a glimpse. It seemed to me that we stood there in silence, straining our eyes at the dark bushes for a long time. Finally, our patrol, two older campers, appeared coming from another direction. They properly and ceremoniously identified themselves. Then they asked what happened. They heard us yelling. Did we see someone? We told them that we thought someone may be in a bush near us. It definitely was not an animal. Much bigger than animal. It was really shaking. They went to the bush and checked it out. Nothing. No sound, no shadowy silhouette, nobody! They asked us how 
long were we on the post - and we said that it was a long time now. They said it was time to get back to our rooms. We did our job well, they said...

I slept so soundly that night (whatever was left of it). In the morning, I found out that "we" saved the flag, indeed! But I felt a bit ashamed for "M"...

On Jakljan we also engaged in various arts: drama, music, dance, art, theater, film, etc. We passionately practiced various sports - first of all, swimming, diving and water polo, but also, soccer, volleyball, basketball, etc. Every evening we had some kind of a "program" that we prepared for ourselves. We made bon-fires with singing, dancing and story-telling. We had "dancing parties", dancing to popular music of the $60 \mathrm{~s}$ - rock-and-roll, twist... We created "poselos" - short programs made out of presentations that each group prepared for the others, including funny sketches, stand-up comedy, games of skills, poetry recitations, etc. We also made theater and filmed movies.

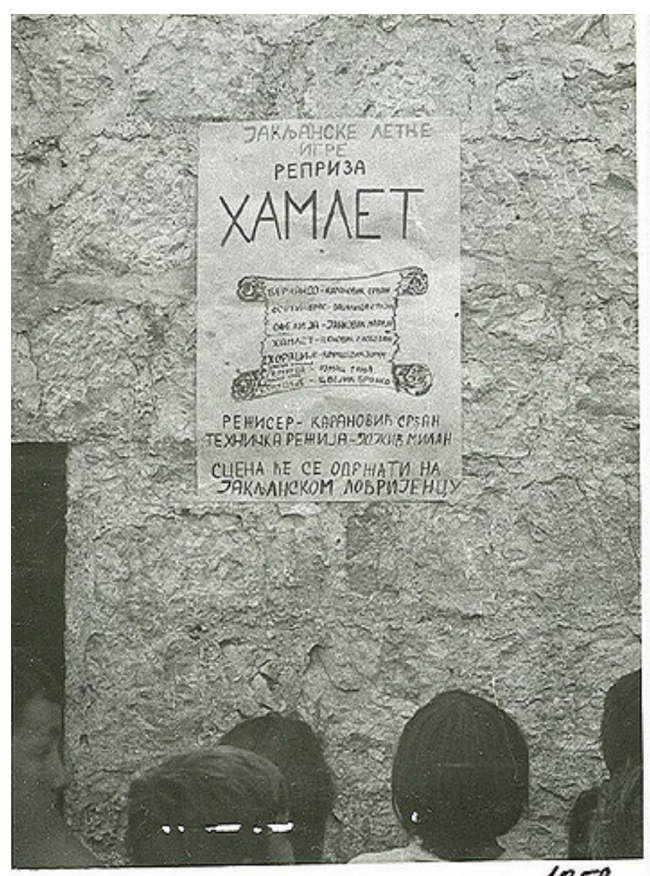

19.58

A handmade poster for the second performance of "Hamlet"
One of the most memorable performances was "Hamlet" 40 , created and directed by several of our friends - who later in life became celebrities, actors, theater and movie directors, musicians - "rockers" (composing and playing rock-and-roll music in self-styled "rock groups"). It is hard to describe the awe of that night, when Hamlet was performed on Jakljan. However, the preparations for this performance were also extensive. To describe this event I use my own memories, supplemented by the memories of the "director of organization." ${ }^{11}$

One has to imagine a small Mediterranean island as almost a complete wilderness: dry, sandy and rocky ground, olive and pine trees, oleander and macchia bushes with their sturdy almost leathery leaves, and a lot of thorny blackberry shrubs. In the midst of one of the olive and pine groves, near the Jakljan beach, stood the ruins of a small chapel, on a slightly elevated sandy plateau. It was not difficult to see that this plateau was almost a natural stage for a show about the medieval Danish prince. Yet, this was also one of the wildest groves with no place for an auditorium, no electric light, no real stage. We built everything from scratch. Micko wrote,

I secured about 20 liters of diesel oil from the "military auxiliary water cistern," which, once a month, used to bring water for our camp. Sailors from that military ship taught us how to make torches using large cans ${ }^{42}$ filled with ashes, sand and rags and adding diesel oil to the mix. Such a torch could last up to 5 hours - just enough for our show. We placed these torches strategically around the plateau, creating a proscenium, and we placed them on top of the remaining chapel walls and the roof - to light our improvised stage (Jojkic, 2015)

\footnotetext{
${ }^{40}$ A photo of the flyer announcing the Jakljan performance of Hamlet can be found here: https://www.flickr.com/photos/jakljanci/263516534/in/album-72157594317478782/

${ }^{41}$ Milan Jojkić, "Mickova Secanja", http://jakljan.pbworks.com/w/page/8349742/Mickova\%20se\%C4\%87anja

${ }^{42}$ These large cans were the packaging for the food that we (Yugoslavia) received as part of the American aid (Marshall plan): cheddar cheese and spam. We also drank powdered milk from the USA.
} 
The scenario for Hamlet was written by two of the campers (who later become a renowned theater and film actor and a film director ${ }^{43}$ ) who also directed the whole performance. Each day of our rehearsals, the excitement grew, as we started to glimpse how this chaos of activities will become a performance. The costumes were made from the bed sheets and blankets. The crowns were made as wreaths of olive twigs.

Since almost all the campers were also the performers (about 100 children), who was going to be the audience? We needed to conjure an audience, somehow, so that our performance could resemble a real theater. We created an amphitheater by placing chairs, benches, tree stumps and some boulders in a few semi-circular rows surrounding our improvised stage. We made a poster (in three handmade copies!) which proclaimed that a performance of "Hamlet" will be staged on "Jakljan Lovrienac.44" The director of our camp, Gaja, [...] sent announcements about our performance to people on the nearby island of Shipan and Dubrovnik [e.g. educators, theater critics, directors, and others engaged in the famous "Dubrovnik Summer Festival"] so that a good number of guests who came to the Jakljan premiere of Hamlet were actually the real theater people (Jojkic, 2015)

The night of the premiere finally came and our audience, all long-faced, pensive, and serious adults we never saw before, finally arrived by the sea in their small motor boats and barks. The daylight slowly turned dimmer and the sky across our bay started to change colors in the sunset. Our dignified audience, one pedagogue after another, one theater critique after another, used to the flamboyant stages of Dubrovnik and the comfort of the plush theater chairs, finally sat down in the improvised amphitheater around the plateau. Micko and his crew started to light the torches, unveiling the darkened contours of the chapel. A faint melody could be heard, seemingly from nowhere - and as the torches guided our gaze, we saw a small boat appear on the horizon against the last rays the sun. A stately figure of the Danish King Claudius stood solemnly on the bow of the boat as it silently docked. All that could be heard now was the splash and the drip of the wet oars. The "people", silhouettes in long robes, appeared on the quay, to great their king. They took his hand as he stepped off the shaky boat and escorted him to the plateau in a procession, as the audience began to applaud even before the performance. When the king reached the plateau, the play started. One scene followed another. When Hamlet returned from the exile, he found Yorick, standing in a half dug grave - a real whole that we dug a few days earlier. Yorick talked to a scull in his hand - a real scull, we found in the chapel earlier that summer, of a poor leper who lived and died there several centuries before $^{45}$. The play went on in the flickering light of the torches with the backdrop of the ruins of the chapel, and the loud sound of the crickets in the night. As we watched, our hearts thumped together, we held our breaths together, we cried real tears with Hamlet's last words: "Oh God, Horatio, ... I'm leaving ... no one knows the truth. If you ever loved me, ... stay in this harsh world [...] and tell my story. ... I am dying!" (Shakespeare, as I remember the sound of these words, in translation to Serbian, of course)

The audience was blown away! Was it possible that children could conceive, organize and produce such a theatrical performance? Gaja, our director, was just reveling together with the guests, while I went to extinguish the already flickering torches, making sure that each one of them was properly doused with water. The guests were enchanted and fascinated. We [the authors of the performance] were jubilant. Gaja "modestly" looked to the ground, enjoying in "his" children, in whom he kindled their best, a spark that never left them throughout their lives (Jojkic, 2015).

\footnotetext{
${ }^{43}$ Branko Cvejić - Cveja and Srdjan (Djidja) Karanović.

44 Lovrienac is a medieval citadel in Dubrovnik, just outside the walls of the Old City. It was used as a natural stage for many Renaissance plays including Hamlet and other Shakespearen performances held there over the years as part of Dubrovnik Summer Festival - https://en.wikipedia.org/wiki/Dubrovnik Summer Festival

${ }^{45}$ The sculls we found may have been much more recent, and much more ominous than we knew at the time. Namely, a few years ago, Croatian media published a story about the communist liquidation of POWs -

http://slobodnadalmacija.hr/Dubrovnik/tabid/75/articleType/ArticleView/articleld/203252/Default.aspx
}

Dialogic Pedagogy: An International Online Journal | http://dpj.pitt.edu DOI: 10.5195/dpj.2018.241 | Vol. 6 (2018) 
Besides "Dom Pionira Beograda" with its summer and winter camps, and its many clubs working through the year, Belgrade developed a rich tapestry of cultural programs, literature, news magazines, theaters, and other projects specially created for children and youth.

\section{Designing a new childhood - "Honorable Children!"}

In 1954, Dušan Radović, a poet, published his first collection of poems for children, under a title "Honorable Children!" This phrase best expresses a sensibility for children that was cultivated in Yugoslavia, beginning in the $50 \mathrm{~s}$, a start of a culturally vibrant historical period of the Yugoslav society spanning the $60 \mathrm{~s}, 70 \mathrm{~s}$ and $80 \mathrm{~s}$. It was marked by a rich production of literary, theatrical, journalistic, TV and film works for children and youth. Many writers wrote poetry, stories and books specifically for children ${ }^{46}$. Books and poetry, journals and newspapers were published and illustrated by some of the best graphic artists of the times. Belgrade had two theaters specifically dedicated to producing plays for children. There were programs where children of Belgrade could meet children of Europe, or talk with celebrities. ${ }^{47}$ Television, introduced in Yugoslavia at the end of the 50 s, became a new medium for experimentation and invention of new video genres for children.

This cultural production for children was deeply inspired by children's play and children's own writing, narratives and drawings. Among the people who created this culture for children, there developed an extraordinary attention and sensitivity to children's ways of seeing and experiencing the world in which they lived. A renowned Yugoslav writer, Dušan Radović said in an online interview,

I write for children. First because I like how children see the world, and because I like that vision of the world. I think there is no richer vision of the world than the way children see it. ... I think that children are the keepers of the secret of this world. And no matter how hard the scientific thinking strives to explain this world, we can expect to be saved by children and by poetry. It is the task of poetry to not to let the secret be discovered. And children, unbeknownst to them, are always at the start of that secret. And because they don't have any knowledge or experience, children are in a direct touch with the world, and always have their own most personal explanations of the things and phenomena around them. ... Those who had a chance to listen to children or to read what children write, especially small children, could see that they are unparalleled in the precise and creative

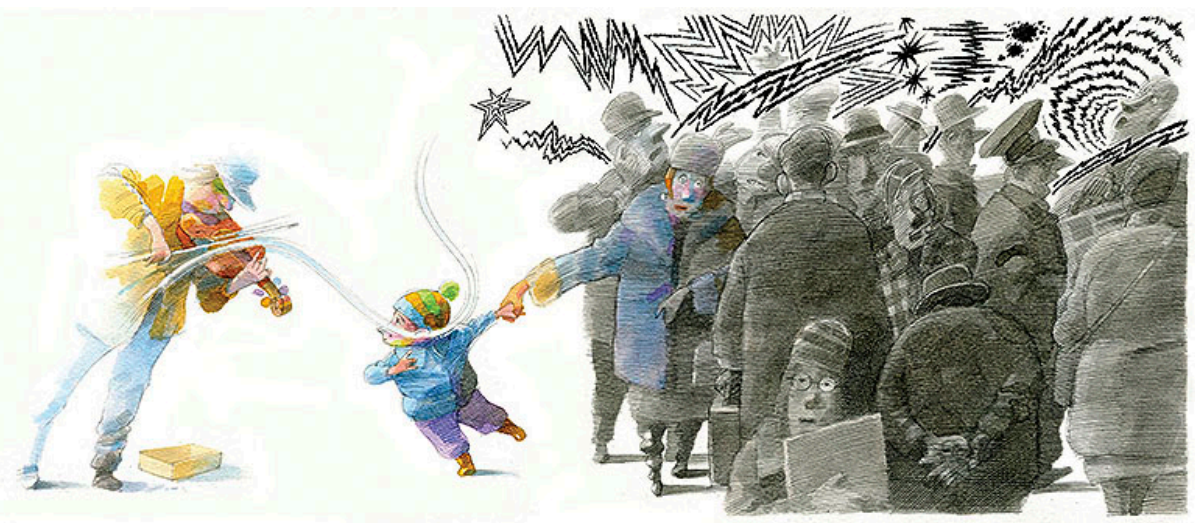

Dušan Petričić, image from The Man with the Violin (c) 2013 Kathy Stinson (text) @2013 published by Annick Press Ltd. Reproduced by permission, all rights reserved.

46 Dušan Radović, Ljubivoje Ršumović, Dragan Lukić, Milovan Danojlic, Mika Antić and many others.

${ }^{47}$ Programs like "The Joy of Europe" and "Thursday Encounters". Many known people (from Yugoslavia, and world-renowned celebrities) participated in these programs. I remember, Neil Armstrong, the first astronaut to walk on the Moon was a guest in "Thursday Encounters" program, and showed us rocks from the moon. 
explanation of the world. Nowhere is the world so rich, as in the stories children tell about it. I think that someone who likes to see the world like that, must have children as the best teaches. ${ }^{48}$

This cultural movement created a novel perspective of the child, and an attempt to create programs based on cultural partnerships with children. It also inspired a number of Yugoslav scholars to search for and to develop a new understanding of the child and child development. They started to create a new approach to education as "open education" - especially in early childhood, an area that was the least colonized by the official "socialist" educational programs, as such small preschool children were not "on the ideological radar" of the official communist education. An open education, according to its proponents, would stop ever growing segregation of children from the mainstream culture and society, reintegrate their lives back onto the mainstream social and cultural life and provide them with an opportunity to participate in the culture not only as its consumers, but also as its co-authors. Cultural clubs like "Dom Pionira" were the examples of such approach where the cultural, artistic, scientific and other activities were "offered" to children without imposition: children had freedom to choose to attend these clubs or not, according to their interests and inclinations. The teaching "curriculum" was usually offered by the "people of culture" (artists, musicians, writers, actors and theater/film directors, scientists, sports coaches, chess players, etc.), known primarily for their original works in the mainstream culture and only secondary for their work with children. And the learning curriculum was chosen by the children and youth through their free attendance or nonattendance in various clubs ("sections").

The scholars from the department of education and psychology of the University of Belgrade, together with their colleagues in other universities of Yugoslavia, became engaged in a whole wave of studies of creativity, play, visual, musical and movement creations by children, and some became leaders and consultants of various educational projects in pre-school institutions and after school programs (Marjanovic-Shane \& Pesic, 2011, September). New programs for pre-school and elementary school children were started in the mid and late 1970s, in which children had freedom to come and go as they wanted, and in which they had opportunities to work together with prominent artists, musicians, actors, scientists, etc. ${ }^{49}$

Some of these programs were still in operation during and after the wars of the 1990's in which Yugoslavia fell apart. However, the wars changed the whole world for the children and the adults, draining the culture, creativity, imagination and "mutual partnerships" out of all - by the sheer brutality, by emigration, and by the political, economic and social desperation that crept in.

\section{A palace between the earth and the sky}

There is a Slavic fairy-tale about a palace that is not on the ground and yet not in the sky ${ }^{50}$. Like all fairy tales, this one, too, describes the struggle between the good and the evil, and like in all fairy-tales after almost unsurmountable obstacles, the good prevails and the evil dies. The palace is between the sky and the earth, and it is full of incredible treasures, beauty, healthy and sumptuous food, pleasant company, and other things that bring happiness, inspiration, and joy. But the palace is owned by a "dragon," an evil

\footnotetext{
${ }^{48}$ Translation of a transcript from an interview Dušan Radović gave in the early 1980s - https://youtu.be/gAvrirs5LZ4. Below the words of Dušan Radović it is a drawing by Dušan Petričić, who had illustrated numerous books by Radović. Although this particular illustration is from a recent book by a Canadian author Kathy Stinson, it perfectly illustrated the spirit of the sensitivity to the children's ways of seeing the world, that Petričić still expresses today, in his contemporary works.

49 One of the most known such programs that lasted 25 years, was "Školigrica", a Belgrade cultural program for children from 4-6 years olds (Beljanski-Ristić, 1983).

50 "Čardak ni na nebu ni na zemlji."
} 
creature who steals people, children, and other earthly creatures, and keeps them in the palace for his own entertainment.

I have described the "golden" part of our childhoods in the 50 s - 70s more than the "cage" part of it, in spite the fact that the evils of the regime in which we lived were not unknown and unfelt by us. In part, I did it because this "golden" side was so different from what seem to have been the possibilities and the opportunities for the children in other socialist countries (as far as I know). But, in part, because I remember what my mother told me a long time ago: that it may be more astonishing that the "evil" can give birth to the "good", than the other way around, that the good may contain seeds of evil ${ }^{51}$. From that point of view, it is not astonishing that we, the children of Yugoslavian socialist regime had games like the "Partisan night", playing out the epic glory of the partisan resistance war against the Nazis. Nor was it astonishing that our camp was organized as an authoritarian, regimented society based on "achieving ranks" (as we did when we achieved to make a "name" for our groups) and on glorifying pure physical labor - as one of the highest socialist values. What is more astonishing is that this socialist society of Yugoslavia, and the life that was organized for us - had so many loopholes in which we, the children and the youth were genuinely supported to develop our imagination, creativity, authorship and agency. For some, my memories may feel like "Yugonostalgia" - a term first coined and used pejoratively for those former Yugoslavs who try to glorify the socialist past. But this is not my sentiment, nor my intent. I do not wish to resurrect the life of the former Yugoslavia.

It is hard for my colleagues and co-authors of this special issue to believe that my memories and my privileged point of view have a lot to do with the ideological becoming of the majority of the Yugoslav children and youth. Yet, from the start of the 1960s, Yugoslavia was an open country and an open society in many ways: the citizens could freely travel out of the country and back. Yugoslav "Gastarbeiters"52 worked in the Western Europe freely travelling between their home in Yugoslavia and their work in Germany, or France, or perhaps Sweden. At the end of the 60s, in 1967, Belgrade got BITEF - Belgrade International Theatre Festival - a yearly occasion to see the newest experimental theatrical productions from all over the world. Yugoslavia imported movies from all over the world, a good majority from the United States and Western Europe, but also from many other countries, including those in the Eastern Bloc. In the mid 70s, a film festival was founded in Belgrade- known as "Fest" - a festival of the movies that won prizes in other world festivals (Oscars, Emmy Awards, Cannes Festival, UK Film festival, etc.). The popular Western youth music of the 60s, 70s, 80s and on - could be heard throughout Yugoslavia, and many Yugoslav youth music bands started to play "rock," "heavy metal," "punk" and other music genres. The summers created opportunities to meet other young people, mostly from Europe, who were attracted to the Yugoslav Adriatic coast by the increasing number of possibilities for cheap camping in the rising Yugoslav tourist industry. Yugoslavia hosted international students from many non-allied countries.

If one characteristic can be highlighted as the predominant for most of the Yugoslav youth, it was a spirit of internationalism. Paradoxically for its overall authoritarian regime, even

... from the perspective of official youth politics, 'internationalism' was seen as 'an integral part of the socialist upbringing of young people'. The desired level of familiarity with contemporary international relations, the social and political movements around the world, the international labour movement, and the politics of peaceful coexistence was to be achieved through programmes of youth

\footnotetext{
${ }^{51}$ For my mother it was a reflection on when, during the WWII, she and her parents were literally rescued and sent to safety out of a concentration camp by the very commander of that camp, an unabashed murderer and a torturer, who, on daily basis, used to kill people on the spot by a shoot in the head - but that is an altogether different story.

52 "Gastarbeiter" is a German word for a "guest worker" - many of whom migrated to Germany and other West European countries in the $50 \mathrm{~s}, 60 \mathrm{~s}$ and $70 \mathrm{~s}$, as part of part of a formal guest worker program.
} 
exchange and mobility... In the words of Borka Pavičević (born 1947), a playwright and cultural activist who took part in the 1968 student protest, 'I think for my generation internationalism was something completely natural. It need not be labelled as such, but it was that ideational, public and literary convergence - Marx, Mao, Marcuse, the Frankfurt School. All of that existed as one spiritual milieu' (Spaskovska, 2017).

However, I immensely wonder and still don't fully understand the set of circumstances and the people - those among our parents, our teachers and those who created the Yugoslav "cultural scene" who had a vision and boldness to create an environment for a childhood in which the children and youth could be freed, at least in a good part, from being fully molded and manipulated into submission, obedience and docility. What, for me, became a message from childhood, is a line of poetry "Oh, be yourself! ${ }^{53 "}$ This was what my high school professor of Serbo-Croatian language and literature ${ }^{54}$, asked us, the new high school students, to write down in our notebooks as a guiding motto, on the very first day of our first grade in high school.

So, I wonder how such an unreal place was possible. Because our childhood in the socialist Yugoslavia was a little like that palace - neither in the sky, nor on the ground. It was a curious, and unusual window in time and space, in which we lived protected, inspired, creative and authorial lives. Yet, in spite of that, we were also in the grips of the uncompromising, ruthless and evil dragon. For a short time in terms of history, we believed that the dragon was dead. But, after all, that is possible only in a fairy tale.

\section{References}

Abrams, L. (2016). Oral history theory: Routledge.

Bakhtin, M. M. (1986). Speech genres and other late essays (M. Holquist \& C. Emerson, Trans. 1st ed.). Austin: University of Texas Press.

Bakhtin, M. M. (1991). The dialogic imagination: Four essays by M. M. Bakhtin (C. Emerson \& M. Holquist, Trans.). Austin, TX: University of Texas Press.

Bakhtin, M. M. (1994). Aesthetic Visualizing of Time/Space: The Chronotope. In P. Morris (Ed.), The Bakhtin Reader: Selected Writings of Bakhtin, Medvedev, Voloshinov (pp. 180-186): Arnold.

Bakhtin, M. M. (1999). Problems of Dostoevsky's poetics (Vol. 8). Minneapolis: University of Minnesota Press.

Beljanski-Ristić, L. (1983). Školigrica: program studija stvaralačkog vaspitanja i estetskog obrazovanja za decu predškolskog uzrasta pri Centru za kulturu "Stari Grad" u Beogradu ["Play-School" -- A Program of Creative and Aesthetic Education for Preschool Children at the Cultural Centre "Stari Grad" i Beograd. Predškolsko Dete [Pre-School Child], 1-2(1983).

Cvetković, S. (2011). Žrtve komunističkog revolucionarnog terora u Srbiji posle 12. septembra 1944.(Istraživanja Državne komisije za tajne grobnice). HERETICUS-Časopis za preispitivanje prošlosti(01+ 02), 9-36.

Despot, Z. (2008, June 25, 2008). Tito, 1968.: Hapsite, ja ne pregovaram [Tito in 1968: Arrest them, I won't negotiate]. Večernji list. Retrieved from http://www.vecernji.hr/hrvatska/tito-1968-hapsite-ja-ne-pregovaram$\underline{841553}$

Dobrivojević, I., Duda, I., Mihelj, S., \& Panić, A. (2014). They Never Had It Better? Modernization of Everyday Life in Socialist Yugoslavia.

Erdei, I. (2006). “The Happy Child” As an Icon of Socialist Transformation: Yugoslavia's Pioneer Organization. In J. R. Lampe \& M. Mazower (Eds.), Ideologies and national identities: the case of twentieth-century Southeastern Europe (pp. 154-179 ). Budapest; new York: Central European University Press.

Jojkic, M. (2015). Mickova sećanja [Micko's memories]. Retrieved from http://jakljan.pbworks.com/w/page/8349742/Mickova\%20se\%C4\%87anja

\footnotetext{
53 “Oj, budi svoj" is a poem by August Šenoa, a Croatian poet from the $19^{\text {th }}$ century -

http://webograd.tportal.hr/Miha29/knjizevnost/knjizevnici/augustsenoa

${ }^{54}$ Olivera Zečević, professor srpsko-hrvatskog jezika, Druge Beogradske Gimnazije
} 
Kotek, J., \& Rigoulot, P. (2000). Le siècle des camps: Détention, concentration, extermination, cent ans de mal radical. Paris: Lattès.

Lampe, J. R., Prickett, R. O., \& Adamović, L. S. (1990). Yugoslav-American Economic Relations Since World War II: Duke University Press.

Lotman, Y. (1988). Text within text. Soviet Psychology, 24(3), 32-41.

Marjanovic-Shane, A., \& Pesic, M. (2011, September). Significant educational concepts and themes developed by the Belgrade School of Creativity, "Belgrade School of Studies on Creativity, Play and Art in Learning and Development". Paper presented at the Third Conference of ISCAR (International Society for Culture and Activity Research), September 5 -10, 2011, Rome, Italy.

Matusov, E., \& Brobst, J. (2013). Radical experiment in dialogic pedagogy in higher education and its centaur failure: Chronotopic analysis. Hauppauge, NY: Nova Science Publishers.

Matusov, E., Marjanovic-Shane, A., \& Gradovski, M. (2018 in preparation). Dialogic Pedagogy and Polyphonic Research: Bakhtin by and for Educators: Palgrave Macmillan.

Matusov, E., \& von Duyke, K. (2010). Bakhtin's notion of the Internally Persuasive Discourse in education: Internal to what? (A case of discussion of issues of foul language in teacher education). In K. Junefelt \& P. Nordin (Eds.), Proceedings from the Second International Interdisciplinary Conference on perspectives and limits of dialogism in Mikhail Bakhtin Stockholm University, Sweden June 3-5, 2009 (pp. 174-199). Stockholm: Stockholm University.

Ngunjiri, F. W., Hernandez, K.-A. C., \& Chang, H. (2010). Living autoethnography: Connecting life and research. Journal of research practice, 6(1), 1.

Popov, N. (2008). Robespjer pod lipama [Robespierre under the linden trees]. Večernje Novosti Online. Retrieved from http://www.serbianna.com/columns/savich/090.shtml

Popović, V. (2008, June 3, 2008). Belo usijanje crvenog univerziteta [The white heat of the red university], Report. Večernje Novosti. Retrieved from http://www.novosti.rs/vesti/naslovna/reportaze/aktuelno.293.html:216610Belo-usijanje-crvenog-univerziteta

Savich, C. (2007). Yugoslav Dissidents during the Cold War. Retrieved from http://www.serbianna.com/columns/savich/090.shtml

Shachtman, M. (1948). Stalinism on the Decline: Tito versus Stalin, The Beginning of the End of the Russian Empire. New International, 14(6), 172-178.

Spaskovska, L. (2017). The Last Yugoslav Generation: The Rethinking of Youth Politics and Cultures in Late Socialism. Oxford, UK: Oxford University Press.

\section{(cc) EY}

New articles in this journal are licensed under a Creative Commons Attribution 4.0 United States License.

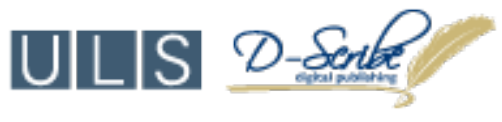

This journal is published by the University Library System, University of Pittsburgh as part of its D-Scribe Digital Publishing Program and is cosponsored by the University of Pittsburgh Press. 